\title{
Research on the Teacher Training Mode of Innovation Practice Education for Mechanical Majors
}

\author{
Chunling $\mathrm{Li}^{1,2, \mathrm{a}^{*}}$, Yufeng $\mathrm{Lu}^{1,2, \mathrm{~b}}$ \\ ${ }^{1}$ School of Mechanical \& Automotive Engineering, Qilu University of Technology (Shandong \\ Academy of Sciences), Daxue Road, Jinan, China \\ ${ }^{2}$ Shandong Institute of Mechanical Design and Research, Jinan, China \\ alcl_Alice@126.com, ${ }^{b}$ luyf78@126.com \\ *Corresponding author
}

Keywords: teacher training mode, innovation ability, practice ability, teamwork ability

\begin{abstract}
One of the goals of higher education teaching reform in China is to cultivate college students' innovative and practical ability. A professional and excellent teachers' team is very important to innovation practice education. The problems in teacher training were analyzed according to the present situation of innovation practice education in universities. The teacher training mode of innovation practice education for mechanical majors was explored. Results showed that teachers' innovative and practical teaching ability has been greatly improved.
\end{abstract}

\section{Introduction}

The purpose of innovation practice education in universities is to cultivate college students' practice ability, innovation ability and teamwork ability. The goal of innovation practice education in universities is to cultivate college students' practice ability, innovation ability and teamwork ability. Modular robot is a reconfigurable robot composed of multiple autonomous modules. It has the advantages of low cost, entry difficulty, high openness, scalability, intelligence and sustainable upgrading, and integrates entertainment, competition and classroom teaching. Modular robot has become the preferred platform for cultivating students' innovative and practical ability.

Teachers play a supporting and guiding role in the process of cultivating college students' innovative practical ability. Therefore, a professional and excellent teachers' team is very important to innovation practice education. Innovation practice education in China started later, compared with many western developed countries. The ability of teachers in innovation practice education in many colleges and universities is not strong enough, resulting in the unsatisfactory effect of innovation practice education. Moreover, many teachers of innovation practice education in universities are directly selected from the teachers of the school. These teachers are not rich in innovation practice experience and social experience, and lack the professional quality of innovative education. Moreover, the team building of teachers is also very important. Many universities have obvious differences in teachers' ability in innovation practice education, but they lack a scientific system to carry out training and management for teachers, which restricts the 
smooth development of innovation practice education to a certain extent. The teacher training mode of modular robot education for mechanical majors was researched aiming at the current situation of robot innovation and practice education in universities.

\section{Problems in College Teacher Training of Innovation Practice Education}

\subsection{Low Training Quality and Effectiveness}

Training quality and effectiveness are important in improving college teachers' innovation practice education ability. At present, the biggest challenge encountered in innovation practice teaching is that there is no relevant teacher training. With the rise of innovation practice education, a huge teacher training market has emerged in recent years. However, due to the lack of systematic management, it is difficult for college teachers to distinguish training qualification and quality. The authority and creativity of training of innovation practice education were reduced owing to the loose training market. Teachers lack real and effective training experience. At present, most of the teacher training has high theory and low effectiveness. Universities strongly support teachers to participate in teacher training of innovation practice education outside the school, and teachers are also aware of their lack of teaching ability and the importance of participating in relevant training, but the improvement of teaching ability is often ineffective.

\subsection{Lack of Platform for the Construction of Teaching Staff}

Regional co-constructing and sharing platform is also a powerful measure in improving teaching ability generally recognized by teachers. At present, the teaching staff construction of innovation practice education in universities in a region is still in the state of "going it alone". There is a lack of joint construction and sharing platform of teaching staff among schools and between schools and enterprises. Teachers of innovation practice education in universities need a platform of coconstruction and sharing. First, they can exchange practices and experiences of innovation practice education with the help of the platform; Second, all universities can share teachers with the help of the platform. This can make up for the construction of part-time teachers in specific majors of innovation practice education in universities, and improve the professionalism and stability of parttime teaching teams. Third, with the help of platform, teachers can go deep into member enterprises for temporary training and investigation and learning, so as to improve their teaching ability of innovation practice education.

\section{Training Mode of Improving College Teachers' Innovative Practical Teaching Ability}

\subsection{Building a professional teacher training system}

A scientific teacher training system should be established to improve the teachers' level of innovation practice education and comprehensive ability from all aspects. The teachers' team of innovation practice education was constructed in combination with scientific management mechanism and robot technology application.

\subsubsection{Establishing a Teacher Training Evaluation Mechanism for Robot Innovation Practice Education}

It is necessary to establish an evaluation mechanism on the basis of attaching great importance and supporting teachers to participate in relevant training outside the school, in order to improve the teaching ability of innovation practice education in universities. Information-based office process is 
usually followed that teaching units or individuals apply to participate in training courses outside the school and then it is approved by the leader of teacher training management department. After the training, the training certificate shall be filed and the expenses incurred shall be reimbursed by the finance department. Thus we can see that, the whole office process of training lacks the feedback of training quality evaluation, which may waste the financial and human resources of the school and is not conducive to the effective improvement of teachers' innovation practice teaching ability. Therefore, it is necessary to add an evaluation part in the training management office process. The teachers participating in the training make subjective evaluation on the whole training quality. The five-star rating system can be used to evaluate the training quality. If the evaluation level is lower than the set threshold, early warning information will be generated or the process will be terminated for future teacher training.

\subsubsection{Construction of Teachers' Professional Knowledge System}

Robot technology covers professional knowledge in many fields, which is the theoretical basis of robot technology innovation practice education. Teachers should improve their own theoretical basis to further guide students. Teachers need to deeply understand the knowledge connotation of the combination of robot technology and innovation practice education, and pay attention to the social development situation, and strengthen the integration of theoretical knowledge and social cases, and constantly enrich their knowledge application ability.

\subsubsection{Teacher Experience Training}

Teachers are required to have certain professional knowledge and pay attention to the practicality of innovation practice education. So some successful entrepreneurial talents can be arranged to communicate with teachers. Teachers can participate in innovation projects of enterprises. In this way, teachers can gain some practical experience and apply it to innovation practice education effectively.

\subsection{Building a Teacher Training Platform for Robot Innovation Practice Education}

The teacher training platform contains three parts, the training of engineering practice innovation projects and creative robot technology knowledge, the introduction of creative robot theme activities and related contest platform, robot competition case sharing.

The training content is based on engineering education, including machinery, materials, electronics, computer software and hardware, control, power and other disciplines. The content of innovation practice training is mainly comprehensive, designed and applied. The application of modern industrial technology integrating industrialization and industrialization, management ideas and team cooperation spirit show the ways and ideas of cultivating the ability of "engineering practice innovation", and provide a new platform for the cultivation of engineering practice innovation ability in universities. The participating teachers can master the connotation of innovation practice education and learn robot innovative education technology, deeply understand the teaching mode and method of engineering practice innovation project, improve practical and innovative thinking ability, and further improve the corresponding teaching ability of cultivating innovative talents.

\section{Conclusion}

The sustainable modular robot teacher training mode was put forward according to the current situation of robot education in universities. The cultivation of innovative talents is critical in the 
current national innovation education reform. We know that the cultivation of innovative talents will not happen overnight and it requires huge investment and the unremitting efforts and accumulation of educators. Modular robot education can shorten the training cycle of innovative talents, reduce the investment of education funds and accelerate the training of teachers. It is an important part of the training system of innovative and applied talents. It should be pointed out that the modular robot innovation practice education teacher training system is not perfect, which needs to be continuously enriched in the teacher training of innovation practice education and tested in the educational practice.

\section{Acknowledgements}

This work was financially supported by teaching research project of Qilu University of technology(2020zd10), and integration of industry and education and collaborative education project of the ministry of education(202002009036, 202002105036).

\section{References}

[1] Su Xing, Zhou Yiyang.Research on improving the Teaching Ability of university teachers' Innovation and Entrepreneurship Education[J]. Journal of Qiqihar University( Phi\& Soc Sci), 2020(11):167-169.

[2] Zhang Xiaoli, Wang Peng, Cui Donghui, Fan Chunfeng and Li Cailing, Research on the cultivation of students' innovative practical ability by robot competition[J]. Education Teaching Forum, 2015(6):87-88.

[3] Meng Minghui, Li Sha, Research on the cultivation of students' innovative practical ability based on Robot Competition [J]. Technology and Economic Guide, 2020,28(21):158.

[4] Xu Chao, Shan Jing, Song Fei, Meng Fanyu, Ding Yong, Design and Implementation of Innovation Experiment Based on Modular Robot [J]. Journal of Liaoning University Natural Sciences Edition, 2018,45(2):129-132.

[5] Zhang Yunliang, Study on Teachers Training in Local Application-Oriented Undergraduate University [J]. Journalof Xi'an University of Arts and Science (Social Sciences Edition), 2009,12(5):60-63.

[6] Liu Jie, Jin Nan, Wang Donghua, Ding Bohui, Practical Exploration of Teaching and Academic Competence Construction of University Teachers-Taking the International Teaching on Academic Teachers Training [J]. Journalof Tianjin University (Social Sciences ), 2018,20(6):566-570.

[7] Du Mingyue, The Research of Innovative Teacher Training Model Based on Teacher's Teaching Ability Development [J]. Medicine Teaching in University, 2019,9(2):57-60.

[8] Quan Lingtong, Wang Xin, University Faculty Training in China: Present Situation, Problems and Optimal Path [J]. Teacher Education Forum, 2017,30(5):62-69. 